A. Yu. Dreus ${ }^{1}$, Dr. Sc. (Tech.), Assoc. Prof., orcid.org/0000-0003-0598-9287, A.A. Kozhevnykov $^{2}$, Dr. Sc. (Tech.), Prof., orcid.org/0000-0002-6876-4168,

Baochang Liu ${ }^{3}$, PhD, Prof., orcid.org/0000-0002-0185-3684, D. A. Sudakova ${ }^{2}$, Cand. Sc. (Tech.), Assoc. Prof., orcid.org/0000-0002-8676-4006
1 - Oles Honchar Dnipro National University, Dnipro, e-mail: dreus@mmf.dnulive.dp.ua

2 - Dnipro University of Technology, Dnipro, Ukraine, e-mail: aak2@ua.fm

3 - College of Construction Engineering, Jilin University, Chanchung, China, e-mail: liubc@jlu.edu.cn

\title{
APPROXIMATE ANALYTICAL MODEL OF ROCK THERMAL CYCLICAL DISINTEGRATION UNDER CONVECTIVE COOLING
}

Purpose. Development of an approximate analytical method for calculating strength reduction of different rocks under thermal cycling effects, taking into account the intensity of convective heat transfer.

Methodology. To solve the problem, an analytical approach based on the thermoelasticity theory was used within the framework of the Griffiths model of fragile fracture.

Findings. It is demonstrated, that cooling of the previously heated rock formation stipulates for intensifies of the rock decomposition process, due to developing fractures zone and decreasing rock strength. Methods for calculating were developed and effect of the intensity of convective heat transfer on crack opening processes in the rock was studied. The results of calculation of destruction time lag for various rocks are presented. It is shown that the efficiency of thermal cyclic decomposition depends on the type of rock.

Originality. A new approximate analytical approach to the investigation of the development of initiated cracks in mining rocks under thermal cyclic load and cooling applied to the surface is proposed. An analytical expression has been obtained for the relationship between the parameters of the fracture process and the parameters of the cooling process. Theoretical substantiation of the use of variable thermal effects on the rock to improve the efficiency of rock destruction during drilling has been carried out.

Practical value. The outcomes of the study can be used to estimate of the parameters of the heat exchange processes to provide effective rock disintegration during drilling. The studies carried out confirmed the possibility of control of the temperature mode on the working face and thermal softening of the rock by changing the flow rate of the drilling fluid.

Keywords: thermal disintegration of rocks, thermal impact, thermoelasticity, Griffith theory, crack opening, drilling efficiency

Introduction. Thermal impact on rock is one of the most effective ways of rock weakening and disintegration. High temperatures induce a number of physical effects in the rock including the thermal expansion and polymorphic transitions [1], changes in mechanical properties [2], changes in acoustic properties [3], the surface cracking intensification [4], etc. Thus, the thermal impact on the rock provides the basis for various contactless technologies used for rock decomposition: spallation drilling [5], laser drilling [6], plasma drilling [7] and plasma reaming of boreholes [8].

An effective way of thermal strength degradation in rocks is to use the alternation of "heating-cooling" cycles [9]. When the heated surface is shock cooled, thermal shrinkage produces tensile stresses, which could lead to opening microcracks. This effect is intentionally used to create promising alternative techniques for rock disintegration [10]. At the same time, as demonstrated in [11], thermal cyclic impact on rock also occurs in traditional drilling techniques, where there is a temperature difference between the flushing liquid and the heated surface of the rock. The experimental data [12] indicate that thermal cyclic impact is an additional factor that intensifies the process of rock destruction and is a reserve for increasing the mechanical drilling speed.

The theory of thermal cyclic disintegration of rocks was developed by A. N. Moskalev, Ye. Yu. Pigida, L. G. Kerekelitsa and Yu. N. Vakhalin (Institute of Geothechnical Mechanics, Dnipro, Ukraine). In [13], the approach was proposed to theoretically substantiate strength reduction of rock in the diamond core drilling process. However, the models considered are limited to the case of shock cooling corresponding to the thermal boundary conditions of the first type. But in practical drilling technologies, the intensity of convective heat transfer between the rock face and the circulating fluid shall be considered.

The purpose of the present work is to develop an analytical model for mining rock loosening under thermal cyclic

(C) Dreus A. Yu., Kozhevnykov A. A., Baochang Liu, Sudakova D. A., 2019 impact with consideration of the intensity of convective heat transfer.

Physical Backgrounds. We shall deal with the problem of mining rock loosening under cyclic impact of hot and cold temperatures on the working face area. The problems of this kind are called heat shock problems in the theory of thermoelasticity [14].

For the processes of mechanical rotary drilling, this impact is provided by alternating contact of the mining rock with the heated indenters of the rock cutting tool and the circulating drilling mud. In particular, when drilling with diamond heads, the time of contact between the working face and cold liquid is hundredths of a second. The experimental data [15] and theoretical estimation [16] demonstrate that normally the nominal washing modes provide intensive cooling of the working face during rotary drilling. Thus, under normal flushing conditions, the temperature difference at the bottom is up to $300{ }^{\circ} \mathrm{C}$, which is not enough to effectively realize the thermal cyclic effect. However [17], the use of pulsed flushing modes allows a temperature difference of $600{ }^{\circ} \mathrm{C}$ to be reached.

The rock mass surrounding the well and bottom hole area are in a stressed state under the effect of high values of the rock pressure [18]. We shall only consider the stresses that arise in the rock due to the changing temperature regime on the surface. The influence of other mechanical factors will be disregarded.

Analysis of outcomes of the research of thermal and thermal-cycling disintegration of rock formation demonstrates that strength reduction of rock formation in defined by the two mutually related criteria: thermal gradient between the heated rock formation and cooling environment, and disintegration delay time. The time of delay is the interval after beginning of cooling required to initiate the fracture development process. Let us assume the mining rock to be an elastic half-space. In the first approximation, we shall neglect the dependence of the physical, mechanical and thermophysical properties of the rock on temperature. 
The state of the surface rock under alternating thermal effects on the face can be described as follows. In the heating phase, the rock is heated to a certain depth and normal compressive stresses arise in it. In the cooling phase, the stresses change the sign, and tensile thermal stresses are induced. The maximum value of thermal stresses is determined by expression

$$
\sigma_{\max }=\frac{\beta \cdot E \cdot\left(T_{\text {hot }}-T_{\text {cool }}\right)}{1-\mu},
$$

where $\beta$ is the coefficient of linear thermal expansion; $E$ is the rock elasticity modulus; $T_{h o t}$ is the heating temperature; $T_{\text {cool }}$ is the cold liquid temperature; $\mu$ is the mining rock Poisson's ratio.

Mining rocks usually contain a network of microcracks distributed through the rock mass with a certain density, some of which reach the free face. In addition to these natural cracks, other cracks are formed when processed by a mechanical rock cutting tool. Some of them will reach the free surface and will open under thermally induced tensile stress.

It should be noted that, as a result of cooling, the fractures in the rock do not develop immediately, but after some minimum necessary time interval, which is called the delay time $\tau_{\min }$ and which depends on the difference $\left(T_{\text {hot }}-T_{\text {cool }}\right)$.

Let us consider the behavior of a single crack in the mining rock under the influence of a thermal stress field within the framework of the Griffiths model of brittle fracture, which is often used to study the processes of rock destruction [19]. The relationship between $\sigma_{\max }$ and the minimum crack length $l_{c r}$ opened under such stress is determined by the Griffiths relationship

$$
\sigma_{\max }=\frac{K \sqrt{2}}{\pi \sqrt{l_{c r}}},
$$

where $K$ is the rock elastic constant. Constant $K$ is related to the energy to create new crack surfaces $\gamma$, Young's modulus of elasticity $E$ and Poisson's ratio $\mu$ as follows

$$
K^{2}=\frac{\pi \cdot E \cdot \gamma}{1-\mu}
$$

The transition of a crack from an equilibrium state to a mobile state is determined by the condition [13]

$$
\pi N_{0}>K
$$

where $N_{0}$ is the stress intensity factor (SIF) at the crack tip.

Solving Heat Transfer Problem. Let us determine the temperature fields in the rock not considering the presence of microcracks. Given the above assumptions, the nonstationary temperature distribution in a rock mass is determined by the heat conduction problem

$$
\rho c \frac{\partial T}{\partial \tau}=\frac{\partial}{\partial x}\left(\lambda \frac{\partial T}{\partial x}\right) ; \quad \tau>0 ; \quad 0 \leq x \leq \infty,
$$

under the initial condition

$$
\left.T\right|_{\tau=0}=T_{0},
$$

and boundary conditions

$$
\begin{gathered}
\left.T\right|_{x=0}=T_{h o t}, \quad \text { if } \quad \tau \in \delta \tau_{1} ; \\
-\left.\lambda \frac{\partial T}{\partial x}\right|_{x=0}=h\left(\left.T\right|_{x=0}-T_{\text {cool }}\right), \quad \text { if } \quad \tau \in \delta \tau_{2} ; \\
\left.\frac{\partial T}{\partial x}\right|_{x \rightarrow \infty}=0,
\end{gathered}
$$

where $\rho$ is the rock density; $c$ is the heat capacity of rock; $\tau$ is time; $\lambda$ is the rock thermal conductivity coefficient; $\delta \tau_{1}$ is the heating phase time; $\delta \tau_{2}$ is the cooling phase time; $T_{0}$ is the rock initial temperature; $h$ is the heat transfer coefficient.

For a one-cycle impact, the solution of problem (4-6) is as follows

$$
\left.\begin{array}{c}
\text { if } 0<\tau<\delta \tau_{1} \text {, then } \\
T(x, \tau)=T_{0}+T_{h o t} \cdot \varphi_{1}(x, \tau), \\
\text { if } \delta \tau_{1}<\tau<\delta \tau_{1}+\delta \tau_{2}, \text { then } \\
T(x, \tau)=T_{0}+T_{h o t} \cdot \varphi_{1}\left(x, \delta \tau_{1}\right)+ \\
+\left(T_{\text {cool }}-T_{h o t}\right) \cdot \varphi_{2}\left(x, \tau-\delta \tau_{1}\right)
\end{array}\right\}
$$

where the functions $\varphi_{1}$ and $\varphi_{2}$ are determined from the heat conductivity equation for the first and third type boundary conditions, respectively

$$
\begin{gathered}
\varphi_{1}(x, \tau)=\operatorname{erfc}\left(\frac{x}{2 \sqrt{a \tau}}\right) \\
\varphi_{2}(x, \tau)=\operatorname{erfc}\left(\frac{x}{2 \sqrt{a \tau}}\right)- \\
-\exp \left(\frac{h}{\lambda} x+\left(\frac{h}{\lambda}\right)^{2} a \tau\right) \operatorname{erfc}\left(\frac{x}{2 \sqrt{a \tau}}+\frac{h}{\lambda} \sqrt{a \tau}\right),
\end{gathered}
$$

where $a$ is the thermal diffusivity coefficient of the rock.

If we know the temperature distribution, we can then determine the fracture parameters using (1,2 and 3).

Simulating Thermal Tensile Stresses. The most dangerous of all the cracks that reach the half-space boundary are those perpendicular to its boundary (Fig. 1).

Let us consider a two-dimensional problem of stretching a crack with a rectilinear contour. Let us assume that the crack surfaces are free from stresses, and the heat flow through the crack surface is zero. The physical and mechanical characteristics of the rock within the cooled layer are assumed to be constant, which is true for a single crack with an infinite rectilinear contour

We need to solve integral equation to describe the start of rock crack process. This equation is obtained from (3) and has form [13]

$$
N_{0}=\frac{\sqrt{2 l}}{\pi} \int_{0}^{l} \frac{\sigma(x)}{\sqrt{l^{2}-x^{2}}} d x .
$$

In general case, the equation (10) does not have a solution in an analytical form. Thus, an approximate approach to problem solution will be applied.

After the transition from heating to cooling, tensile stresses are induced in the surface layer of the rock parallel to the boundary of the half-space, which are described taking into account (7-9) by expression

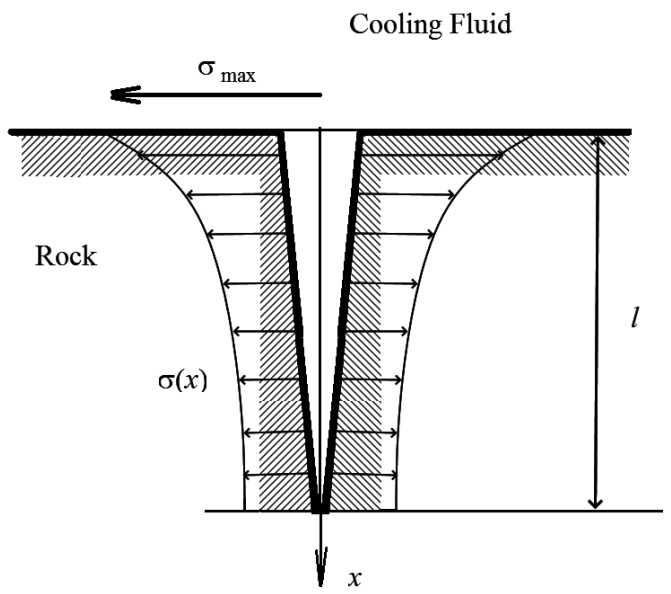

Fig. 1. Diagram for calculations of thermal stresses 


$$
\begin{gathered}
\sigma(x, \tau)=\sigma_{*}\left[\left[\operatorname{erfc}\left(\frac{\xi}{2 \sqrt{\mathrm{Fo}}}\right)-\right.\right. \\
\left.-\exp \left(\mathrm{Bi} \xi+\mathrm{Bi}^{2} \mathrm{Fo}\right) \operatorname{erfc}\left(\frac{\xi}{2 \sqrt{\mathrm{Fo}}}+\mathrm{Bi} \sqrt{\mathrm{Fo}}\right)\right],
\end{gathered}
$$

where $F o=\frac{a \tau}{l_{c r}^{2}}$ is the Fourier number; $B i=\frac{h l_{c r}}{\lambda}$ is the Biot number; $\xi=x / l_{c r}$.

The linear approximations of functions $\varphi_{1}, \varphi_{2}$, to describe temperature fields in the mining rock are introducing therein. Thus, we shall write (9) in the form of a linear dependence on $\xi$

$$
\tilde{\varphi}(\xi, F o)= \begin{cases}1-\exp \left(\mathrm{Bi}^{2} \mathrm{Fo}\right) \operatorname{erfc}(\mathrm{Bi} \sqrt{\mathrm{Fo}})- & \xi \leq \xi_{0} . \\ -\mathrm{Bi} \exp \left(\mathrm{Bi}^{2} \mathrm{Fo}\right) \operatorname{erfc}(\mathrm{Bi} \sqrt{\mathrm{Fo}}) \cdot \xi & \\ 0, & \xi>\xi_{0}\end{cases}
$$

Approximating a function $\varphi$ by the function $\tilde{\varphi}: 1-$ Fo $=$ $=0.1, \mathrm{Bi}=5 ; 2-\mathrm{Fo}=0.5, \mathrm{Bi}=2$. Given $\xi \leq \xi_{0}$ (Fig. 2), where the values $\xi_{0}$ are determined according to the formula

$$
\xi_{0}=\frac{1-\exp \left(\mathrm{Bi}^{2} \mathrm{Fo}\right) \operatorname{erfc}(\mathrm{Bi} \sqrt{\mathrm{Fo}})}{\operatorname{Biexp}\left(\mathrm{Bi}^{2} \mathrm{Fo}\right) \operatorname{erfc}(\mathrm{Bi} \sqrt{\mathrm{Fo}})},
$$

the error of this approximation is about $19 \%$.

The work by prof. Murakami Y. and Hasebe N. (Murakami, Y., \& Hasebe, N. Stress intensity factors handbook, Elsevier Science) demonstrates that if $\sigma(x)$ can be represented in the form

$$
\sigma(x)=-\sigma \sum_{n=0}^{10} C_{n}\left(\frac{x}{l}\right)^{n},
$$

where $C_{0}, C_{1}, \ldots, C_{10}$ are arbitrary constants, then the stress intensity factor for a single crack can be approximated as

$$
\begin{aligned}
& N_{0}=-\sigma \sqrt{2 \pi l}\left(0.7930 C_{0}+0.4829 C_{1}+0.3716 C_{2}+\right. \\
&+0.3118 C_{3}+0.2735 C_{4}+0.2464 C_{5}+0.2260 C_{5}+ \\
&\left.+0.2090 C_{6}+0.1968 C_{8}+0.1858 C_{9}\right) .
\end{aligned}
$$

Let us limit expansion of (13) to the first two terms. By equating right-hand members of $(10,11,12)$ and $(13)$, we will find coefficients $C_{0}, C_{1}$. Using (2, 3 and 13) we get the equation relating the parameters $\mathrm{Bi}$, Fo and the dimensionless crack length $L=\frac{l}{l_{c r}}$ at the transition of the crack to the mobileequilibrium state

$$
\sqrt{\frac{1}{L}}=0.895 \cdot A(F o, B i)-0.545 \cdot B(F o, B i) \cdot L,
$$

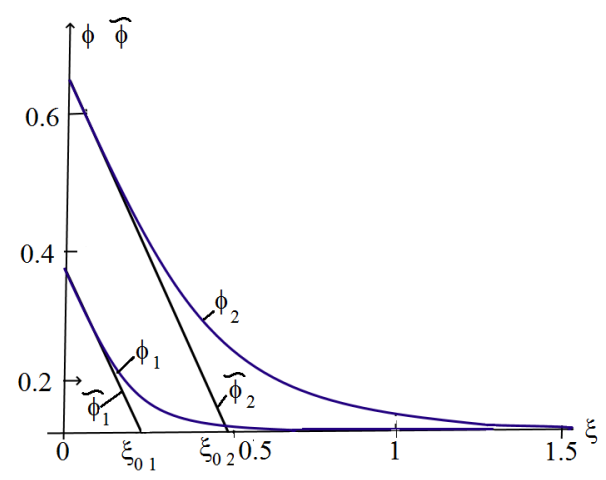

Fig. 2. Approximating a function $\varphi$ by the function $\tilde{\varphi}$ : $1-\mathrm{Fo}=0.1, \mathrm{Bi}=5 ; 2-\mathrm{Fo}=0.5, \mathrm{Bi}=2$ where $A(\mathrm{Fo}, \mathrm{Bi})=1-\exp \left(\mathrm{Bi}^{2} \mathrm{Fo}\right) \operatorname{erfc}(\mathrm{Bi} \sqrt{\mathrm{Fo}}), \quad B(\mathrm{Fo}, \mathrm{Bi})=$ $=-\mathrm{Bi} \exp \left(\mathrm{Bi}^{2} \mathrm{Fo}\right) \operatorname{erfc}(\mathrm{Bi} \sqrt{\mathrm{Fo}})$.

We shall write equation (14) in the form

$$
y^{3}+p y+q=0,
$$

where $y=\sqrt{L} ; \quad p=-1.642 \cdot \frac{A(\mathrm{Fo}, \mathrm{Bi})}{B(\mathrm{Fo}, \mathrm{Bi})} ; \quad q=\frac{1.835}{B(\mathrm{Fo}, \mathrm{Bi})}$.

Equation (15) is the canonical form of the cubic equation. Note that $p<0$, so, if the condition is met,

$$
\frac{q^{2}}{4}+\frac{p^{3}}{27}<0
$$

then equation (15) has three real roots, which are easily determined according to the Cardano formula

$$
y_{k}=2 \sqrt{\left(\frac{-p}{3}\right)} \cos \left(\frac{\mathrm{v}+2 k \pi}{3}\right),
$$

where $\mathrm{v}=\arccos \left(\frac{-q}{2 r}\right) ; r=\sqrt{\frac{(-p)^{3}}{27}} ; k=1,2,3$.

Numerical calculations in the study of rock destruction showed that one of the three real roots (16) is negative, which does not meet the introduced condition $y=\sqrt{L}$. Two other roots can be used to write the solution (14)

$$
L_{1}=\frac{4}{3} p \cos ^{2}\left(\frac{v}{3}\right) ; \quad L_{2}=\frac{4}{3} p \cos ^{2}\left(\frac{v+6 \pi}{3}\right) .
$$

As we can see, there are two positive values of the crack length $\mathrm{L}$ for one moment of time Fo. These values correspond to the points on the down and up branches on the graph shown below.

Results. Let us consider the impact of the heat exchange rate on the surface of the mining rock on the delay in the onset of the fracture process. Fig. 3. shows the results of calculating the Fourier number (dimensionless delay time) depending on the Biot number, which acts as a dimensionless heat transfer coefficient.

All curves describing the relationship between the Fourier number and the length of the crack have a minimum point. Proceeding from the definition of $l_{c r}$, it is obvious that cracks of length $l<l_{c r}(L<1)$ will not grow. If $L>1$, two options are possible. If $1<L<L_{\min }$, then the cooling time is short, and the rock is stretched without any visible fissuring.

Moskalev A. N. et al. (Moskalev, A. N., Pygida, E. Yu., Kerekilitsa, L. G., \& Vakhalin, Yu. N. Destruction of rocks by

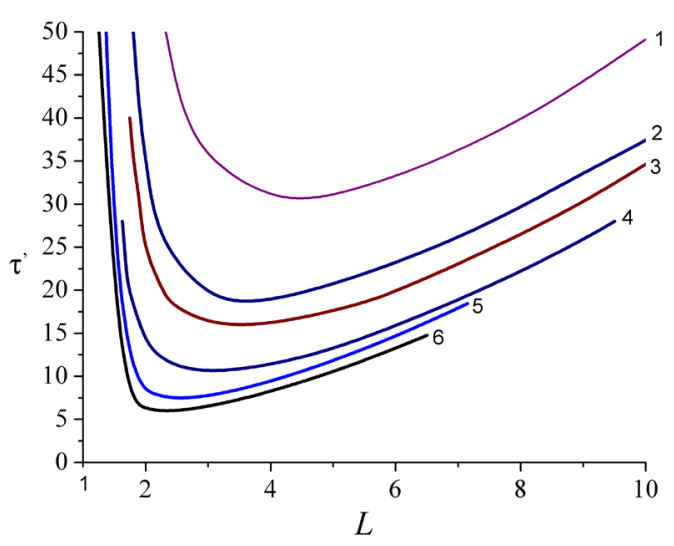

Fig. 3. Dependence of the Fourier number Fo on the dimensionless crack length $L$ for various values of the $\mathrm{Bi}$ number: $1-\mathrm{Bi}=0.5 ; 2-\mathrm{Bi}=1 ; 3-\mathrm{Bi}=1.5 ; 4-\mathrm{Bi}=2 ; 5-\mathrm{Bi}=5 ; 6-$ $\mathrm{Bi} \rightarrow \infty$ 
thermal cyclic impact, Naukova dumka, Kyiv) obtained an analytical relation connecting the delay time with the crack length for the case when $\mathrm{Bi} \rightarrow \infty$, in the form

$$
\mathrm{Fo}=\frac{4}{\mathrm{\partial}^{3}} \frac{L^{3}}{(\sqrt{L}-1)^{2}} .
$$

Curve 6 in Fig. 3 describes the dependence (17). The findings show that as the Bi number increases, the solutions obtained using the proposed model, approach the solution described by the (17). For $\mathrm{Bi}>5$, equation (17) can be used to calculate the fracture parameters.

When $\mathrm{Fo}=\mathrm{Fo}_{\text {min }}$ is reached, the crack starts propagating dynamically and goes to sustained growth. The less is the $\mathrm{Bi}$ number, the more exposure time is required for the mining rock crack transition to a mobile state. As the Bi number decreases, the minimums of the curves shift toward higher values of $L$ (Fig. 4). Thus, for the effective destruction of the rock, longer cracks are required.

Let us consider the productivity of thermal cyclic disintegration for various mining rocks whose properties are presented in Table 1.

Table 2 shows the results of calculating the thermal cyclic destruction parameters of various mining rocks during convective cooling with a heat transfer coefficient of $h=3.6 \times$ $\times 10^{4} \mathrm{~W} /\left(\mathrm{m}^{2} \mathrm{~K}\right)$ from the heated surface. The temperature difference during the transition from heating to cooling is assumed to be $600{ }^{\circ} \mathrm{C}$, which can be reached with conventional rotary diamond drilling.

The findings prove that the thermal cyclic fracture effect is different for different mining rocks. For Granite, Ferrous quartzite and Diorite, the thermal cyclic effect can be seen even after a short-term pulsed reduction in temperature. Although for Sandstone, a much longer exposure to the cooling medium is required for the thermal cyclic destruction.

Note, that experimental results of the study [12] show that in rotary drilling, the temperature difference between the min-

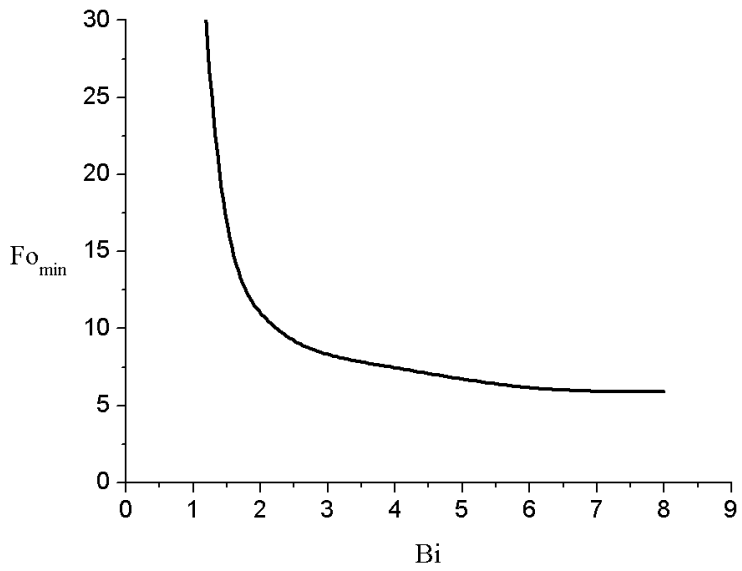

Fig. 4. Dependence of the Fourier minimum $\mathrm{Fo}_{\min }$ on the $\mathrm{Bi}$ number

Table 1

Physical-mechanical and thermophysical parameters of rocks

\begin{tabular}{|l|c|c|c|c|c|}
\hline \multicolumn{1}{|c|}{ Rock } & $\begin{array}{c}E \cdot 10^{10}, \\
\mathrm{~N} / \mathrm{m}^{2}\end{array}$ & $\begin{array}{c}\beta \cdot 10^{-5}, \\
\mathrm{~K}^{-1}\end{array}$ & $\mu$ & $\begin{array}{c}K \cdot 10^{6} \\
\mathrm{~N} / \mathrm{m}^{3 / 2}\end{array}$ & $\begin{array}{c}a \cdot 10^{-6} \\
\mathrm{~m}^{2} / \mathrm{s}\end{array}$ \\
\hline Granite & 2.9 & 1 & 0.1 & 1.7 & 0.89 \\
\hline $\begin{array}{l}\text { Ferrous } \\
\text { quartzite }\end{array}$ & 6.7 & 1.35 & 0.21 & 3.2 & 1.7 \\
\hline Sandstone & 4.9 & 0.25 & 0.28 & 2.37 & 1.22 \\
\hline Diorite & 7.4 & 1 & 0.33 & 1.6 & 0.65 \\
\hline
\end{tabular}

Table 2

Parameters of thermal cyclic destruction of rocks

\begin{tabular}{|l|c|c|c|}
\hline Rock & $\begin{array}{c}\text { Thermal } \\
\text { tensile stress } \\
\sigma_{\max }, \mathrm{N} / \mathrm{m}^{2}\end{array}$ & $\begin{array}{c}\text { The minimum length } \\
\text { of the crack that will } \\
\text { begin to open } l_{c r}, \mathrm{~mm}\end{array}$ & $\begin{array}{c}\text { The destruction } \\
\text { process delay } \\
\text { time } \tau_{\min }, \mathrm{s}\end{array}$ \\
\hline Granite & $1.93 \cdot 10^{8}$ & 0.035 & 0.001 \\
\hline $\begin{array}{l}\text { Ferrous } \\
\text { quartzite }\end{array}$ & $2.42 \cdot 10^{8}$ & 0.07 & 0.004 \\
\hline Sandstone & $5 \cdot 10^{7}$ & 0.1 & 0.99 \\
\hline Diorite & $3.87 \cdot 10^{8}$ & 0.007 & 0.0003 \\
\hline
\end{tabular}

ing rock and the coolant is one of the key factors to increase the drilling speed.

Conclusion. The model and technique is proposed to study the process of thermal softening of the mining rock during the alternation of heating-cooling cycles on the surface.

It is demonstrated that to estimate the delay time of the onset of the fracture process, the intensity of the convective heat transfer on the surface should be taken into account. Based on solving the thermoelasticity problem, an approximate analytical relationship is obtained relating the parameters of the fracture process: the fracture start delay time and the minimum crack length, with the coefficient of convective heat transfer at the working face.

It is shown that the convective cooling time required for the intensification of the fracture process depends essentially both on the intensity of heat exchange between the rock and the coolant and on the physical, mechanical and thermophysical characteristics of the mining rock. For a number of concerned mining rocks (Diorite, Granite, Ferrous quartzite), the effect of thermal loosening of the mining rock can be achieved with rotary drilling, by changing the temperature regime at the bottom-hole. However, when drilling Sandstone, a longer bottom-hole exposure to coolant is required.

\section{References.}

1. Plevova, E., Vaculikova, L., Kozusnikova, A., Ritz, M., \& Martynkova, G.S. (2016). Thermal expansion behaviour of granites. Journal of Thermal Analysis and Calorimetry, 123, 1555-1561. DOI: 10.1007/s10973-015-4996-Z.

2. Chen, Y.-L., Wang, S.-R., Ni, J., Azzam, R., \& Fernándezsteeger, T. M. (2017). An experimental study of the mechanical properties of granite after high temperature exposure based on mineral characteristics. Engineering Geology, 220, 234-242. DOI: 10.1016/j.enggeo.2017.02.010, 71-74.

3. Kong, B., Wang, E., Li, Z., Wang, X., Liu, J., \& Li, Nan. (2016). Fracture Mechanical Behavior of Sandstone Subjected to High-Temperature Treatment and Its Acoustic Emission Characteristics Under Uniaxial Compression Conditions. Rock Mechanics and Rock Engineering, 49(12), 4911-4918. DOI: 10.1007/s00603-016-1011-3.

4. Zhao, Z. (2016). Thermal Influence on Mechanical Properties of Granite: A Microcracking Perspective. Rock Mechanics and Rock Engineering, 49(3), 747-762. DOI: 10.1007/s00603015-0767-1.

5. Kant, M.A., Rossi, E., Madonna, C., Höser, D., \& P. Rudolf von Rohr (2017). A theory on thermal spalling of rocks with a focus on thermal spallation drilling. Journal of Geophysical Research: Solid Earth, 122, 1805-1815. DOI: 10.1002/2016JB013800.

6. Buckstegge, F., Michel, T., Zimmermann, M., Roth, S., \& Schmidt, M. (2016). Advanced Rock Drilling Technologies Using High Laser Power. Physics Procedia, 83, 336-343. DOI: 10.1016/j.phpro.2016.08.035.

7. Kristofic, T., Kocis, I., Balog, T., Gajdos, M., Kocis, I., \& Gelfgat, M. (2016). Well Intervention Using Plasma Technologies. In SPE Russian Petroleum Technology Conference and 
Exhibition, Moscow, Russia, 24-26 October 2016, SPE182120-MS. DOI: 10.2118/182120-MS.

8. Voloshyn, O., Potapchuk, I., Zhevzhyk, O., \& Zhovtonoha, M. (2018). Results of the experimental research of the heat-transfer jet pressure to the rock surface during thermal reaming of the borehole. In E3S Web of Conferences, 60, 00024. DOI: $10.1051 / \mathrm{e} 3$ sconf/20186000024.

9. Zhang, A., Zhao, O., Hu, B., Skoczylas, A., \& Shao, J. (2018). Laboratory Investigation on Physical and Mechanical Properties of Granite After Heating and Water-Cooling Treatment. Rock Mechanics and Rock Engineering, 51(3), 677-694. DOI: $10.1007 / \mathrm{s} 00603-017-1350-8$.

10. Hosseini, M. (2017). Effect of temperature as well as heating and cooling cycles on rock properties. Journal of Mining \& Environment, 8(4), 631-644. DOI: 10.22044/jme.2017.971.

11. Zhang, H., Gao, D., Salehi, S., \& Guo, B. (2014). Effect of fluid temperature on rock failure in borehole drilling, Journal Engineering Mechanics, 140, 82-90. DOI: 10.1061/(ASCE) EM.1943-7889.0000648.

12. Kozhevnykov, A., \& Dreus, A. (2018). Power consumption of rock decomposition process during diamond core drilling using pulse flushing. Mining of Mineral Deposits, 12(3), 22-27. DOI: $10.15407 /$ mining 12.03.022.

13. Dreus, A. Yu., Sudakov, A. K., Kozhevnykov, A.A., \& Vakhalin, Yu. N. (2016). Study on thermal strength reduction of rock formation in the diamond core drilling process using pulse flushing mode. Naukovyi Visnyk Natsionalnoho Hirnychoho Universytetu, 2, 5-10.

14. Zhang, X.-Y., Chen, Z.-T., \& Li, X.-F. (2018). Thermal shock fracture of an elastic half-space with a subsurface penny-shaped crack via fractional thermoelasticity. Acta Mechanica, 229(12), 4875-4893. DOI: 10.1007/s00707-018-2252-x.

15. Shankar, V. K., Kunar, B. M., \& Murthy, C. S. (2018). Experimental investigation and statistical analysis of operational parameters on temperature rise in rock drilling. International Journal of Heat and Technology, 36(4), 1174-1180. DOI: 10.18280/ijht.360403.

16. Dreus, A. Y., \& Lysenko, K. Ye. (2016). Computer simulation of fluid mechanics and heat transfer processes at the working face of borehole rock. Naukovyi Visnyk Natsionalnoho Hirnychoho Universytetu, 5, 29-35.

17. Kozhevnykov, A. O., Dreus, A. Yu., Baochang, Liu, \& Sudakov, A. K. (2018). Drilling fluid circulation rate influence on the contact temperature during borehole drilling. Naukovyi Visnyk Natsionalnoho Hirnychoho Universytetu, 1, 35-42. DOI: 10.29202/nvngu/2018-1/14.

18. Khomenko, O., Kononenko, M., \& Bilegsaikhan, J. (2018). Classification of Theories about Rock Pressure. Solid State Phenomena, 277, 157-167, DOI: 10.4028/www.scientific. net/SSP.277.1.57.

19. Sdvyzhkova, O., Golovko, Y., \& Klimenko, D. (2017). Theoretical substantiation of the rock outburst criterion in terms of amplitude-frequency characteristics of an acoustic signal. In Conference Proceeding $16^{\text {th }}$ International Conference Geoinformatics: Theoretical and Applied Aspects, Kyiv; Ukraine; 15-17 May 2017, 129036. DOI: 10.3997/2214-4609.201701822.

\section{Наближена аналітична модель термоциклічного руйнування гірської породи при конвективному охолодженні}

$$
\text { А. Ю. Дреус }{ }^{1}, \frac{\text { А.О.Кожевников }^{2}}{\text { Д. А. Судакова }}{ }^{2} \text { Баочанг Лю }
$$

1 - Дніпровський національний університет імені О. Гончара, м. Дніпро, Україна, e-mail: dreus.andrii@gmail.com 2 - Національний технічний університет ,Дніпровська політехніка“, м. Дніпро, Україна

3 - Будівельний коледж Цзилінського університету, м. Чанчунь, Китай
Мета. Розробка наближеної аналітичної методики розрахунку знеміцнення гірської породи при термоциклічному впливі з урахуванням інтенсивності конвективного теплообміну.

Методика. Для розв’язання задачі використано аналітичний підхід на основі теорії термопружності в рамках моделі крихкого руйнування Грифітса.

Результати. Показано, що охолодження попередньо нагрітих гірських порід дозволяє значно знизити енергоємність процесу їх руйнування за рахунок розвинення зони передруйнування та послаблення породи. Розроблена методика розрахунку та досліджено вплив інтенсивності конвективного теплообміну на процеси розкриття мікротріщин у породі. Наведені результати розрахунку часу затримки руйнування для різних гірських порід. Показано, що ефективність термоциклічного руйнування залежить від виду гірської породи.

Наукова новизна. Запропоновано новий наближеноаналітичний підхід до дослідження процесу розвинення тріщин у гірській породі при циклічному нагріванні та охолодженні поверхні. Одержано аналітичний вираз, що зв'язує параметри процесу руйнування із процесами охолодження. Виконані теоретичні обгрунтування використання змінного теплового впливу на гірську породу для підвищення ефективності руйнування при бурінні.

Практична значимість. Результати роботи становлять інтерес для оцінки можливості управління температурним режимом буріння та теплового знеміцнення гірської породи за рахунок зміни витрат промивальної рідини.

Ключові слова: термічне руйнування гірських порід, тепловий вплив, термопружність, теорія Грифітса, розкриття тріщин, ефективність буріння

\section{Приближенная аналитическая модель термоциклического разрушения горной породы при конвективном охлаждении}

\section{А. Ю. Дреус ${ }^{1}, \frac{\mid \text { А.А.Кожевников }}{\text { Д. А.Судакова }}{ }^{2}$, Баочанг Лю ${ }^{3}$,}

1 - Днепровский национальный университет имени О. Гончара, г. Днепр, Украина, e-mail: dreus.andrii@gmail. com

2 - Национальный технический университет „Днепровская политехника“, г. Днепр, Украина

3 - Строительный колледж Цзилинского университета, г. Чанчунь, Китай

Цель. Разработка приближенной аналитической методики расчета разупрочнения горной породы при термоциклическом воздействии с учетом интенсивности конвективного теплообмена.

Методика. Для решения задачи использован аналитический подход на основе теории термоупругости в рамках модели хрупкого разрушения Гриффитса.

Результаты. Показано, что охлаждение предварительно нагретых горных пород позволяет значительно снизить энергоемкость процесса их разрушения за счет развития зоны предразрушения и ослабления породы. Разработана методика расчета и исследовано влияние интенсивности конвективного теплообмена на процессы раскрытия микротрещин в породе. Приведены результаты расчета времени задержки разрушения для различных горных пород. Показано, что эффективность термоциклического разрушения зависит от вида горной породы.

Научная новизна. Предложен новый приближенноаналитический подход к исследованию процесса развития трещин в горной породе при циклическом нагреве и охлаждении поверхности. Получено аналитическое 
выражение, связывающее параметры процесса разрушения с параметрами охлаждения. Выполнено теоретическое обоснование использования переменного теплового воздействия на горную породу для повышения эффективности разрушения горной породы при бурении.

Практическая значимость. Результаты работы представляют интерес для оценки возможности использования эффекта термоциклического разрушения в различных технологиях бурения. Выполненные исследования подтвердили возможность управления температурным режимом бурения и теплового разупрочнения горной породы за счет изменения расхода промывочной жидкости

Ключевые слова: термическое разрушение горных пород, тепловое воздействие, термоупругость, теория Гриффитса, раскрытие трещин, эффективность бурения

Рекомендовано до публікації докт. техн. наук В. І. Бондаренком. Дата надходження рукопису 08.12.18. 